\title{
Seashell waste-derived materials for secondary catalytic tar reduction in municipal solid waste gasification
}

\author{
Yamid Gomez-Rueda ${ }^{a}$, Ilman Nuran Zainic, Weihong Yang ${ }^{c}$, Lieve Helsen a,b \\ ${ }^{a}$ Department of Mechanical Engineering, Celestijnenlaan 300, Leuven 3001, Belgium \\ ${ }^{b}$ Energyville, Thor Park, Waterschei, Belgium \\ ${ }^{c}$ Department of Materials Science and Engineering, KTH Royal Institute of Technology, \\ 10044 Stockholm, Sweden
}

\begin{abstract}
Catalytic tar removal from producer gas is critical for the economic feasibility of Municipal Solid Waste (MSW) gasification in the waste-to-energy(WtE) approach. Nickel- and noble-metal catalysts have the highest tar cracking activities, but they increase costs, use scarce materials, and generate dangerous byproducts. To overcome these drawbacks, naturally occurring materials should be used for tar cracking. In this paper, two nanomaterials, synthesized from oyster and mussel waste shells respectively, are used to clean syngas from MSW in a secondary tar cracking unit. We observed that they reform class 1 tar (heavy tars that condense at high temperatures at very low concentrations) into class 3 tar (light hydrocarbons that are not important in condensation) and benzene. Although both catalysts' composition and textural properties were identical, crystallite size and especially specific surface area variation was enough to generate a change in product selectivity. A larger crystallite size and SSA shows a soot yield reduction of $95 \%$ with respect to the non-catalytic case, simultaneously increasing the $H_{2} / \mathrm{CO}$ at $1000^{\circ} \mathrm{C}$.
\end{abstract}


Keywords: Tar removal, gasification, Municipal Solid Waste, green catalyst, Waste-to-Energy

Abbreviations: SSA, Specific Surface Area; ELFM, Enhanced Landfill Mining; Nm3, Normal cubic meter; MSW, Municipal Solid Waste; WtE, Waste-to-Energy; WtM, Waste-to-Materials; PAH, Polyaromatic Hydrocarbons; GC, Gas Chromatography; BET, Brunauer-Emmett-Teller; BJH, Barret-Joyner-Halenda; XRF, X-Ray Fluorescence; XRD, X-Ray Diffraction; SPA/SPE, Solid-phase adsorption / Solid-phase Extraction; ER, Equivalent Ratio.

\section{Introduction}

Human sustainability on earth is being menaced by depletion of natural sources, the impact of waste to the environment (water, air, and soil) and the lack of clean, reliable, affordable and modern energy resources [1]. In response to these challenges, strategies like Enhanced Landfill Mining (ELFM) have gained attention for treating the Municipal Solid Waste (MSW) contained in the 150.000 to 500.000 landfill sites across Europe [2] reducing the environmental impact of such waste while recovering energy (WtE) and materials (WtM) from it. Within the ELFM context, gasification has been evaluated as a technology with a higher potential than incineration or pyrolysis for WtE and WtM valorization routes [3].

Although gasification is a mature technology, MSW gasification is still under study and many challenges need to be overcome to arrive at mass market implementation [4]. One of them is the production of tar, a byproduct of gasification that pollutes the producer gas, and that consists of all 
hydrocarbons with a molecular weight higher than benzene [5]. Tar is a big issue from the operational point of view, causing clogging in pipes and accessories, and from the environmental point of view, playing a significant role in the gasification environmental impact $[6,7,8]$. The main consequence of tar presence in syngas is unacceptable maintenance times, which makes tar removal so costly, that it has caused the disappearance of many gasification projects [8]. Tar can also increase the toxicity risks for all operators in contact with it, increase the rate of corrosion in metallic pipes and devices and increase the deactivation of active sites in supported metal catalysts.

Catalysts have been used as the most popular technology for tar cracking either in-situ (i.e. inside the gasifier together with the feedstock) or ex-situ (in a secondary unit downstream the gasifier) or in both configurations as suggested by Claude et al. [9] in a temperature range of $400-1000^{\circ} \mathrm{C}$. In this temperature range, catalysts convert tar into lighter gases without involving substantial cooling or heating of the producer gas, which makes them ideal for this task, especially when energy valorization is envisaged.

However, the catalysts with the highest catalytic activity, long-term stability, and low carbon deposition during tar cracking contain metals like $\mathrm{Ni}$, $\mathrm{Pt}, \mathrm{Pd}, \mathrm{Rh}$, or $\mathrm{Ru}[10,11,12]$ which have a reduced availability in nature and therefore high prices. The use of cheap greener catalysts (especially the ones derived from waste) has attracted attention of recent research studies to reduce the environmental impact with respect to metal supported catalysts in syngas cleaning [13], or to increase the lifetime of such metal-based catalysts by preconditioning the syngas to avoid their deactivation.

Using waste-derived materials for tar cracking can increase the waste 
treatment performance of the gasification process, by reducing the amount of waste dumped and by finding a cheap greener precursor for tar removal catalysts. Indeed, many waste-derived materials have demonstrated to be effective in various catalytic processes. For instance, red mud, a residue from the aluminum industry, is used in catalytic bio-oil upgrading [14], in coal and biomass hydrogenation [15] and in naphthalene and SOx catalytic reduction [15]; and slags from steel industry are used for aqueous pollutant removal [16]. Apart from the examples given above, there is a long list of materials obtained from waste which have shown to be suitable for being used as catalysts in different processes [17] which can be exploited in tar abatement.

In the specific case of tar reduction, most of the catalysts derived from residues have been obtained from the char [18, 19, 20, 21, 22, 23], and the ashes $[24,25]$ produced from thermochemical treatment of the same feedstock. In addition to the aforementioned materials, calcined waste shells for tar craking purposes have been gaining attention. Thanks to their high calcium content they have been used in processes such biodiesel production [26, 27, 28, 29, 30,31, 32], photocatalytic removal of dyes from water [33], and $\mathrm{CO}_{2}$ capture in gasification and combustion processes [34, 35, 36, 37].

Other calcium-rich materials have been successfully used for tar removal, like calcined dolomite and olivine for biomass tar removal in-situ [39, 40, 41, $42,43,44,45,46]$ and ex-situ $[39,47,48,49,50]$, however both minerals must be exploited in mines. Using waste shells would avoid the mining activity usually linked to the use of dolomite, olivine and other metal-based catalysts, reducing also the environmental impacts associated with it. So far, among 


\begin{tabular}{|c|c|c|c|c|}
\hline $\begin{array}{l}\text { Basis of } \\
\text { classification }\end{array}$ & Nomenclature & Description & Properties & Representative compounds \\
\hline \multirow[t]{5}{*}{$\begin{array}{l}\text { Molecular } \\
\text { weight }\end{array}$} & Class 1 & GC-undetectable & Very heavy tar; undetectable by GC & $\begin{array}{l}\text { Biomass fragments; } \\
\text { heaviest tar }\end{array}$ \\
\hline & Class 2 & Heterocyclic aromatics & $\begin{array}{l}\text { Tar containing hetero atoms; } \\
\text { highly water soluble }\end{array}$ & $\begin{array}{l}\text { Pyridine, phenol, quinoline, } \\
\text { isoquinoline, cresols }\end{array}$ \\
\hline & Class 3 & $\begin{array}{l}\text { Light aromatic } \\
\text { (1 ring) }\end{array}$ & $\begin{array}{l}\text { Light hydrocarbons; do not pose } \\
\text { condensation or solubility problems }\end{array}$ & $\begin{array}{l}\text { Touene, ethylbenzene, } \\
\text { xylenes, styrene }\end{array}$ \\
\hline & Class 4 & $\begin{array}{l}\text { Light PAH compunds } \\
\text { (2-3 rings) }\end{array}$ & $\begin{array}{l}\text { Condense at intermediate } \\
\text { temperatures at high concentrations }\end{array}$ & $\begin{array}{l}\text { Indene, naphthalene, } \\
\text { methylnaphthalene, } \\
\text { phenanthrene, anthracene }\end{array}$ \\
\hline & Class 5 & $\begin{array}{l}\text { Heavy PAH compunds } \\
\text { ( } \geq 4 \text { rings) }\end{array}$ & $\begin{array}{l}\text { Condense at high temperatures } \\
\text { even at low concentrations }\end{array}$ & $\begin{array}{l}\text { Fluoranthene, pyrene } \\
\text { crysene,perylene, coronene }\end{array}$ \\
\hline
\end{tabular}

Table 1: Tar compound classification according to ECN [38]. Acronyms: GC $=$ Gas Chromatography, PAH = Polyaromatic Hydrocarbons.

the different seafood shells available, only scallop and egg waste shells have been investigated for in-situ tar reduction in biomass steam gasification as active phase and as catalyst supports [51, 52, 53, 54].

The addition of in-situ catalysts makes no sense for specific feedstocks, like excavated MSW, due to the high ash and soil content (between $34 \%$ and 60\%) [55], because adding an in-situ catalyst would increase the already enormous amount of ash. Moreover, in the aforementioned studies, only gas composition changes are tracked, but there is no information about the evolution of tar composition and soot generation during the tests, both of which are critical for the design of downstream processes and to evaluate the catalytic tar cracking performance.

There is thus still a need for exploring calcium-rich materials derived from shells as catalyst alone, especially under optimized conditions in a secondary tar cracking unit. Therefore, in this study we explore the catalytic tar reduc- 
tion from MSW gasification using catalysts derived from two type of shells, Crassostrea Gigas and Mytilus Edulis, both of them having a worldwide production of 575.626 and 182.626 tonnes per year respectively [56], generating subsequently significant amounts of waste. The tar catalytic cracking activity is isolated from other catalytic effects by using them in a secondary reactor downstream a MSW gasifier allowing also to find better operating conditions for tar cracking. A detailed tar distribution analysis is done according to the classification made by the Nederlandse Organisatie voor Toegepast Natuurwetenschappelijk Onderzoek TNO (former Energy Center of the Netherlands ECN) presented in table 1, and the tar dew point is determined using the online tool provided by the same institution [57].

\section{Experimental}

\subsection{Municipal Solid Waste preparation}

The MSW used in this research was obtained from a ballistic separation of excavated waste from the Mont-Saint-Guibert landfill in Belgium. For the gasification tests, the lightest waste fraction between $200-90 \mathrm{~mm}$ was selected (also known as a 2D fraction) due to its high calorific value $(22.4 \mathrm{MJ} / \mathrm{kg}$ ) [58]

which is comparable to the one of woody biomass (around $20 \mathrm{MJ} / \mathrm{kg}$ ) [59] and low-rank coals [60] (between 18-24 MJ/kg). The fraction consisted of $0.7 \%$ wood, $3.5 \%$ paper, $8.4 \%$ textile, $42.3 \%$ plastics, $10.5 \%$ other combustible materials, $1.9 \%$ metals, $1.5 \%$ inert materials, and $31.2 \%$ fine particles as was measured by a hand sorting method by García-Lopez et al. [58]. The samples were dried in a furnace at $105^{\circ} \mathrm{C}$ before the gasification tests. The MSW's ultimate analysis revealed that the sample contained $40.5 \%$ of $\mathrm{C}$, 
$6.1 \%$ of $\mathrm{H}, 1.1 \%$ of $\mathrm{N}$, and $4.3 \%$ of $\mathrm{O}$ (in $\mathrm{Wt} \%$ on a dry basis) with the rest of the MSW sample being composed of inorganic minerals and metals. The proximate analysis showed $55.3 \%$ of volatile matter and $42.9 \%$ of ashes with an undetermined amount of fixed carbon (on a Wt\% on a dry basis). The proximate analysis of the MSW sample gives a total composition higher than $100 \%$, which has also been found in other studies dealing with high-ash content samples, due to the high amount of metals and inorganic compounds that oxidize during the proximate analysis making challenging to determine the amount of fixed carbon [61].

\subsection{Catalyst preparation and characterization}

For this research, $1 \mathrm{~kg}$ of Crassostrea Gigas (Oysters) and 1kg of Mytilus Edulis (Mussels) shells were recovered from a local restaurant in the WestVlananderen region of Belgium. Both samples were kept in a $10 \%$ hypochlorite solution to control the odors and bacterial activity before processing the material. Subsequently, the shells were washed with abundant hot water and dried at $110^{\circ} \mathrm{C}$ overnight. After that, the shells were submerged in a $5 \%$ $\mathrm{NaOH}$ solution with ultrasound treatment to remove the remaining organic matter. The shells were then washed with hot water until the $\mathrm{pH}$ was neutral and dried in an oven at $110^{\circ} \mathrm{C}$ overnight. The shells were powdered in a mill and the resulting powders were calcined at $1000^{\circ} \mathrm{C}$ for 4 hours. The calcined materials were again manually ground and subsequently pelleted and crushed to obtain a particle size between 0.8 and $1.2 \mathrm{~mm}$. The two resulting catalysts were labeled as catalyst \#1 for the one derived from mussels and catalyst \#2 for the one derived from oysters. Three characterization techniques were used for determining the physicochemical properties of the different materials 
as described in the next sections.

\subsection{1. $\mathrm{N}_{2}$ physisorption tests}

$\mathrm{N}_{2}$-physisorption tests were performed on a Micromeritics TriStarII Singlepoint and micrometrics FlowSorbIII. The specific surface area was determined on approximately $0.3 \mathrm{~g}$ of powder of each of the two samples with previous degassing at $150^{\circ} \mathrm{C}$ under vacuum during $2 \mathrm{~h}$. The Brunauer-EmmettTeller (BET) theory was applied to calculate the specific surface areas. Pore size distributions were obtained at the same time from the isotherms based on the Barret-Joyner-Halenda (BJH) theory. Desorption branches were used to determine Specific Surface Area (SSA), pore size distributions, pore-volume, and average pore diameter.

\subsubsection{X-ray Fluorescence (XRF)}

The elemental composition of the calcined catalysts was carried out using a wavelength dispersive X-ray fluorescence spectrometer (S2 Ranger Bucker), equipped with a palladium tube. For the analysis $500 \mathrm{mg}$ of each of the two calcined catalysts were placed in a closed vessel covered by a mylar film, a plastic transparent to X-rays.

\subsubsection{X-ray diffraction (XRD)}

Powder X-ray diffraction (XRD) characterizations were carried out at room temperature on a Bruker AXS D8 advance diffractometer in BraggBrentano geometry, with a radiation source of $\operatorname{CuK} \alpha(\lambda=0.154 \mathrm{~nm})$. The XRD pattern was recorded with a step size of $0.05^{\circ}$ in $2 \theta$, at 1 step per second, with a scan range of $20^{\circ}<2 \theta<80^{\circ}$. This study was used to determine the crystalline phases of the materials before and after calcination 
by comparison with XRD patterns in the Bruker database and to calculate the apparent average crystallite sizes. The apparent average crystallite sizes were estimated by full pattern matching of the corresponding XRD structures using equation 1.

$$
d_{\text {cryst }}=\frac{k \times \lambda}{\beta \times \cos \theta}
$$

where $\mathrm{k}$ is the geometric factor $(\mathrm{k}=0.89), \beta$ is the width of the line at half height in radians, $\lambda$ represents the wavelength used and $\theta$ is the angle of Bragg in radians. $\mathrm{A} \mathrm{LaB}_{6}$ standard was used to evaluate the instrument resolution.

\subsection{Tar cracking tests}

The tar catalytic experiments were performed in the setup sketched in Figure 1. Each experiment starts by placing 5g of MSW sample in a holder in

the gasifier cold zone (1) while the hot zone (2) reaches $800^{\circ} \mathrm{C}$. Simultaneously the downstream secondary tar cracking reactor (3) is also heated-up. During heating up, a nitrogen flow is passed through the system, and once the final temperature is reached, the flow is switched to air with an Equivalent Ratio (ER) of 0.45 , and the MSW sample is moved from the gasifier cold zone to the gasifier hot zone. The ER is the ratio of the fuel-to-oxidizer ratio to the stoichiometric fuel-to-oxidizer ratio. The value of 0.45 was chosen because it is a typical value used in gasifiers working above $800^{\circ} \mathrm{C}$ [62], also allowing to form tar concentrations that do not saturate the SPA column used for sampling.

Once the sample is placed in the hot zone, gases are released from the sample in the reactor (2), pass through the second reactor (3) and, then, 


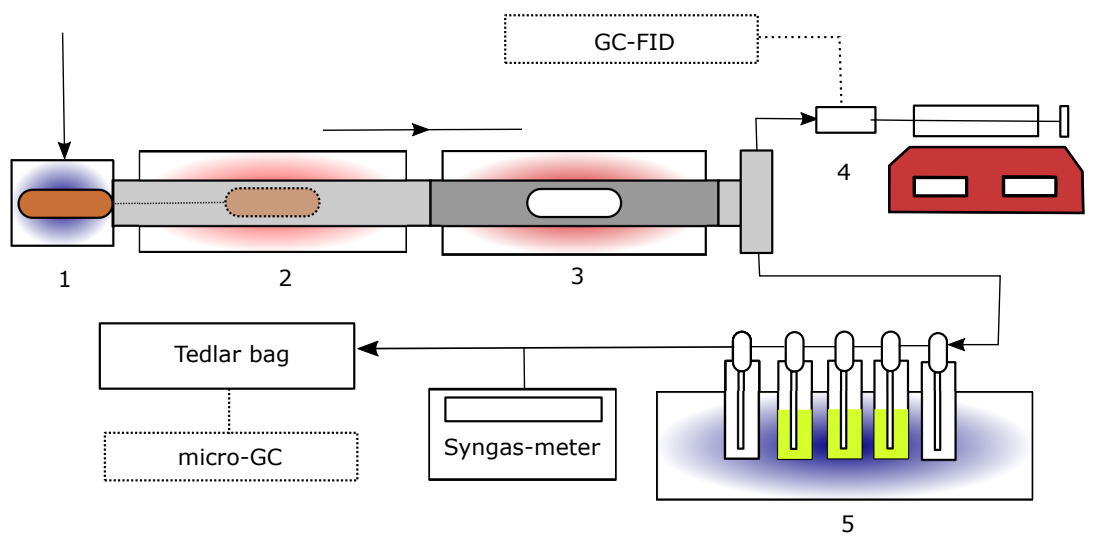

Figure 1: Catalytic test setup. The dotted lines represent off-line measurements while the solid lines represent online analysis. Parts: 1. Gasifier cold-zone 2. Gasifier hot-zone 3. Secondary tar cracking reactor 4. SPA/SPE sampling 5. Tar scrubbing system.

through a set of bottles containing acetone at $-12^{\circ} \mathrm{C}(5)$ in order to remove tar, while SPA/SPE sampling (4) is done in parallel by sampling $100 \mathrm{ml}$ of gas during the first $5 \mathrm{~min}$ of gasification. After the scrubbing section, the gases passed are directed through a glass wool filter placed before gas collection in a Tedlar-bag, to be later subjected to a micro-GC analysis to determine the gas speciation. The syngas yield was measured by an online gas flow-meter. The SPA/SPE column is processed according to the procedure described in [63] to identify and quantify tar molecules from class 2 to class 5 according to the classification shown in table 1 , while the scrubbing liquid contained in the bottles is filtered, evaporated $\left(80^{\circ} \mathrm{C}\right.$ during $\left.12 \mathrm{~h}\right)$ and weighted to determine the gravimetric tar yield, which will be referred to as class 5 tar in the Results section. The soot yield is determined by the amount of solid retained during filtering of the scrubbing liquids.

In the different experiments carried out, the conditions in the first reactor 
(1) and (2) are kept invariable, while in the secondary tar cracking unit the temperature and the type of catalyst are varied according to the experimental matrix displayed in Table 2. During the non-catalytic test, an empty boat was kept in the secondary tar cracking reactor, while in the other experiments the boat was filled with 5 grams of catalyst.

\begin{tabular}{lll}
\hline Tar removal method & Tar removal temperature & \\
\hline Thermal cracking (No catalyst) & $800^{\circ} \mathrm{C}$ & $1000^{\circ} \mathrm{C}$ \\
Catalyst \#1 (Mussel-derived) & $800^{\circ} \mathrm{C}$ & $1000^{\circ} \mathrm{C}$ \\
Catalyst \#2 (Oyster-derived) & $800^{\circ} \mathrm{C}$ & $1000^{\circ} \mathrm{C}$ \\
\hline
\end{tabular}

Table 2: Tar cracking experimental matrix.

\section{Results}

\subsection{Characterization of the catalysts}

According to XRF tests, both catalysts showed to be rich in calcium with small strontium impurities amounting $99.5 \%$ of calcium and $0.5 \%$ strontium after calcination. Although the elemental composition was similar, there appeared small differences when characterizing the porosity of the materials. From the $N_{2}$ physisorption tests, presented in figure 2, both catalysts produced before and after calcination a type IV isotherm, with a very small area hysteresis loop, indicating the presence of low mesoporosity. The pore volume, pore size and SSA obtained from the BET analysis of the $\mathrm{N}_{2}$ isotherms are presented in table 4 , where it is clear that catalyst \#1 has a lower porosity than catalyst $\# 2$, with a SSA of 0.164 and $0.364 \mathrm{~m}^{2} \mathrm{~g}^{-1}$ respectively. This SSA is very low compared to other porous catalysts usually used for tar 
cracking, though calcium-rich materials obtained from similar sources exhibited also very low SSA values [11], as it can be seen in table 3. The mean pore diameter was $41.5 \mathrm{~nm}$ for catalyst \#1 and $28.87 \mathrm{~nm}$ for catalyst \#2.

\begin{tabular}{|l|l|r|l|}
\hline Type & Catalyst & $\mathrm{SSA}\left(\mathrm{m}^{2} \mathrm{~g}^{-1}\right)$ & Reference \\
\hline \multirow{4}{*}{ Biochar } & Iron supported on bio- and coal char & $400-1400$ & {$[64]$} \\
\hline \multirow{5}{*}{ Zeolite } & Fly ash supported on char & 117 & {$[65]$} \\
\hline \multirow{5}{*}{ Ca-based materials } & Ni-MgO over HZSM-5 & $281-316$ & {$[66]$} \\
\cline { 2 - 4 } & Olivine & $0.15-1.42$ & {$[67]$} \\
\cline { 2 - 4 } & Olivine & 0.18 & {$[68]$} \\
\cline { 2 - 4 } & Dolomite & 17.92 & {$[68]$} \\
\cline { 2 - 4 } & Dolomite & 0.18 & {$[68]$} \\
\cline { 2 - 4 } & Ni and Fe supported on Olivine & $1-8,8$ & {$[48]$} \\
\hline \multirow{5}{*}{ Others } & MgO & $0.81-2.95$ & {$[69]$} \\
\cline { 2 - 4 } & $\gamma$-Alumina & 34 & {$[70]$} \\
\hline
\end{tabular}

Table 3: Typical Specific Surface Area (SSA) of different catalysts used for tar cracking

Regarding the crystal structure, the non-calcined materials showed clear differences, while after calcination, both materials were more uniform as is clear from figure 3. Before calcination, catalyst \#1 presented two different phases, aragonite, and calcite, while catalyst \#2 consisted only of calcite. After calcination at $1000^{\circ} \mathrm{C}$, both materials evolved towards $\mathrm{CaO}$, with catalyst \#2 showing higher intensity peaks. The only clear difference between both catalysts was the crystallite size estimation, obtained by using equation 1 , over the different peaks, which was of $67 \pm 4,4 \mathrm{~nm}$ for catalyst $\# 1$ and 

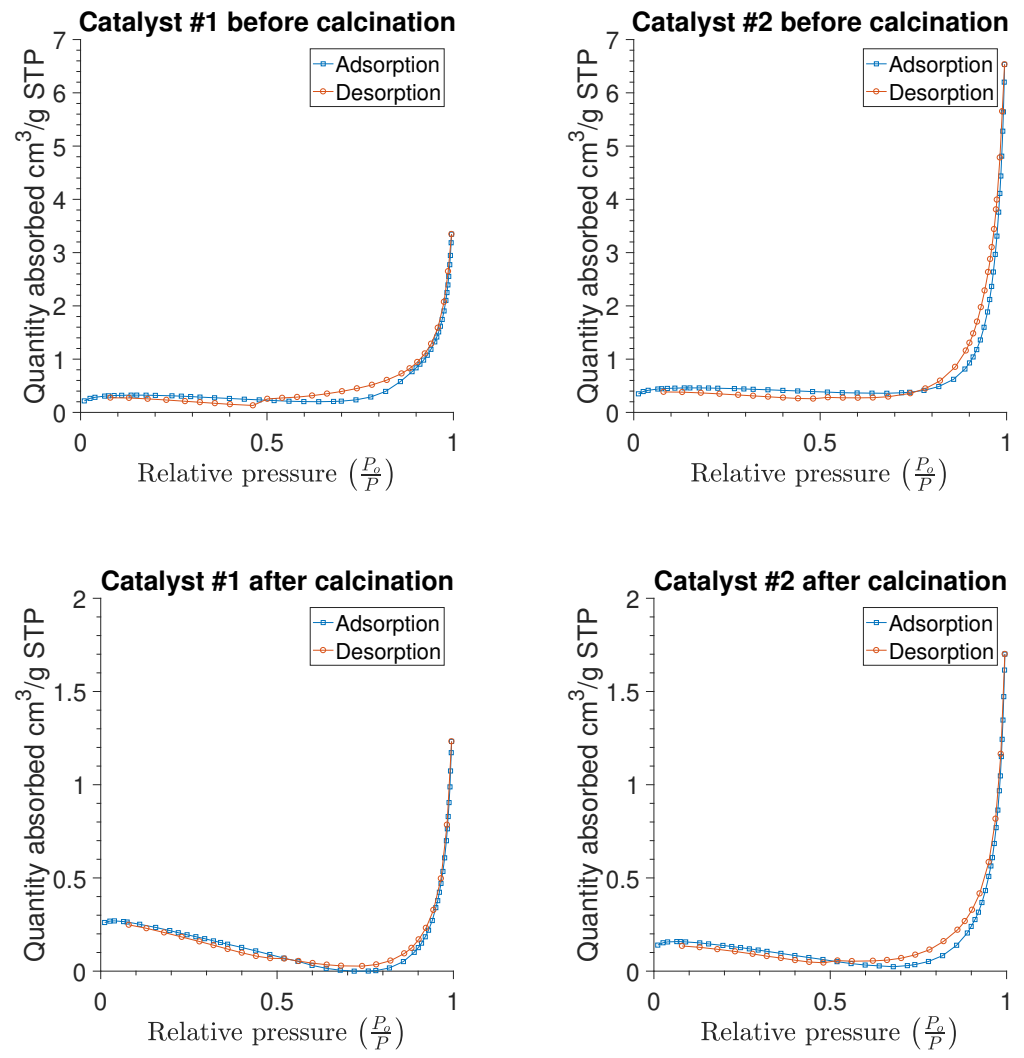

Figure 2: $\mathrm{N}_{2}$ adsorption-desorption analysis of mussel and oyster derived materials before and after calcination.

$77 \pm 8,8 \mathrm{~nm}$ for catalyst $\# 2$.

\subsection{Syngas yield and composition}

The use of both catalysts increased notably the syngas yield at $800^{\circ} \mathrm{C}$, when compared to the non-catalytic case, with catalyst \#1 showing a higher syngas yield increment. However at $1000^{\circ} \mathrm{C}$, the effect of the catalysts on syngas yield is less obvious, and it can be considered as negligible. Syngas composition, on the other hand, exhibited a higher variation at $1000^{\circ} \mathrm{C}$ for both catalysts when added in the secondary tar cracking unit as can be seen 


\begin{tabular}{clll}
\hline Catalyst & $\begin{array}{l}\text { SSA } \\
\left(\mathrm{m}^{2} \mathrm{~g}^{-1}\right)\end{array}$ & $\begin{array}{l}\text { Pore volume } \\
\left(\mathrm{cm}^{3} \mathrm{~g}^{-1}\right)\end{array}$ & $\begin{array}{l}\text { Pore size } \\
(\mathrm{nm})\end{array}$ \\
\hline \#1 non-calcined & 0.969 & 0.005 & 26.57 \\
$\# 2$ non-calcined & 1.400 & 0.010 & 43.27 \\
$\# 1$ calcined & 0,164 & 0.002 & 63.06 \\
$\# 2$ calcined & 0,364 & 0.003 & 39.87 \\
\hline
\end{tabular}

Table 4: BET analysis of calcined and non-calcined catalysts
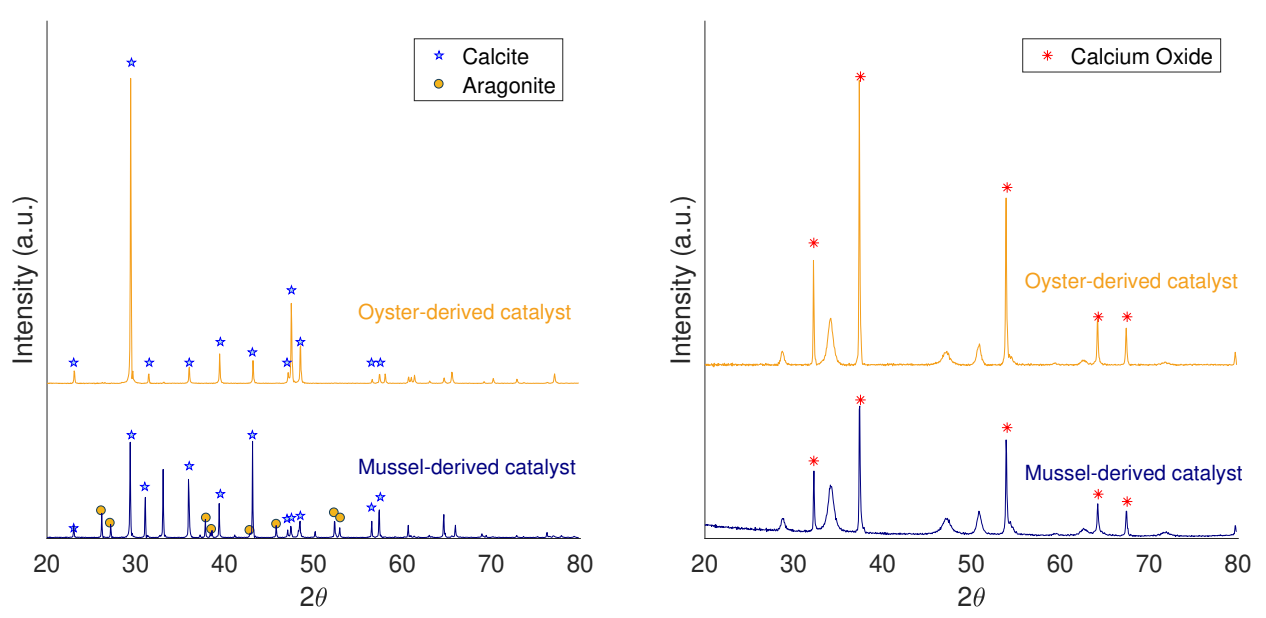

Figure 3: XRD patterns of non-calcined (left) and calcined (right) materials.

in figure $4 \mathrm{~b}$.

The $\mathrm{H}_{2}$ volume fraction was 3 times higher at $1000^{\circ} \mathrm{C}$ than at $800^{\circ} \mathrm{C}$ for the catalytic and non-catalytic cases, which agrees with what is expected from a temperature increment $[71,72,73]$. The use of catalyst \#1 however, resulted in a slightly higher volume fraction of $\mathrm{H}_{2}$ when compared to the non-catalytic case, while the use of catalyst \#2 decreased the $\mathrm{H}_{2}$ volume fraction. The $\mathrm{CO}_{2}$ fraction followed an opposite trend, but with volume 


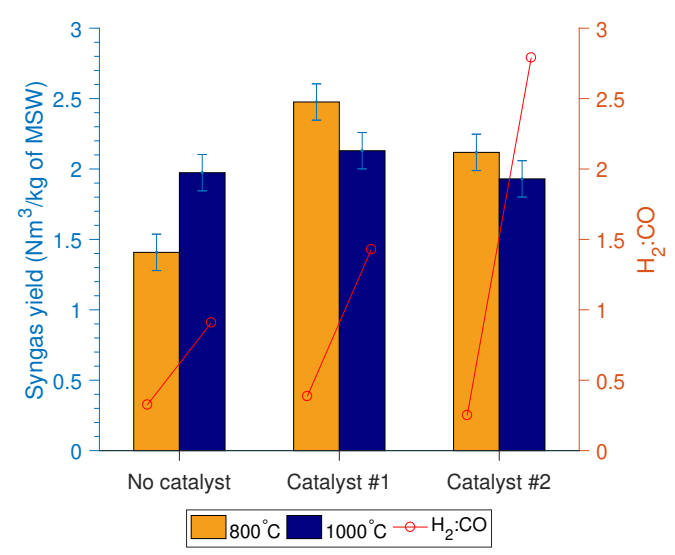

(a)

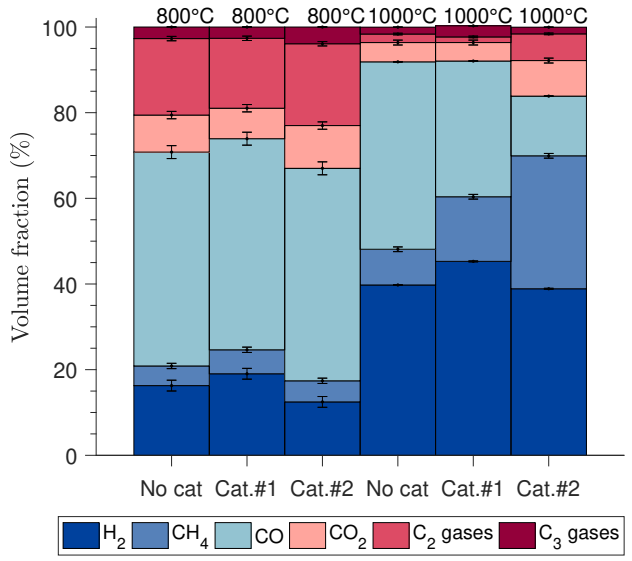

(b)

Figure 4: Syngas yield (4a) and syngas composition (4b) in a $\mathrm{N}_{2}$ free basis.

fractions much lower than the ones of $\mathrm{H}_{2}$.

$\mathrm{CO}$ and $\mathrm{CH}_{4}$ fractions followed different trends at both temperatures studied. At $800^{\circ} \mathrm{C}$, the use of both catalysts did not seem to affect the volume fraction of either of these two gases. On the other hand, at $1000^{\circ} \mathrm{C}$, $\mathrm{CO}$ fraction was reduced by both catalysts while the $\mathrm{CH}_{4}$ fraction increased, with catalyst \#2 displaying the most notable variation of these two gases compared to the non-catalytic case.

The $\mathrm{C}_{2}$-gases (which comprise ethylene and acetylene) also showed a different behavior with the two catalysts at the two temperatures studied. While at $800^{\circ} \mathrm{C}$ catalyst \#1 reduced their fraction and catalyst \#2 did not, at $1000^{\circ} \mathrm{C}$ catalyst \#2 increased the $\mathrm{C}_{2}$-gases fraction by 4 while catalyst \#1 kept it almost invariable in comparison to the non-catalytic case.

With respect to the $\mathrm{H}_{2}$ : $\mathrm{CO}$ ratio the use of both catalysts had a negligible effect at $800^{\circ} \mathrm{C}$ but they both presented a beneficial effect at $1000^{\circ} \mathrm{C}$, passing from 0.9 in the non-catalytic case, to 1.4 and 2.8 for catalyst \#1 and \#2 
respectively.

In summary, catalyst \#1 increased more the syngas yield, hydrogen, and methane fraction while catalyst \#2 increased more moderately (or even decreased) the syngas yield and the hydrogen fraction at both temperatures. At $800^{\circ} \mathrm{C}$ the syngas yield variation was more evident in comparison to the noncatalytic case, while at $1000^{\circ} \mathrm{C}$ syngas composition was more affected than the syngas yield. Even when catalyst \#2 reduced the $\mathrm{H}_{2}$ yield, the $\mathrm{H}_{2}$ : $\mathrm{CO}$ ratio was highly improved by using this catalyst, reaching a maximum value of 2.8 but with a simultaneous higher production of $\mathrm{C}_{2^{-}}$and $\mathrm{C}_{3}$-gases(which comprise propene and propane).

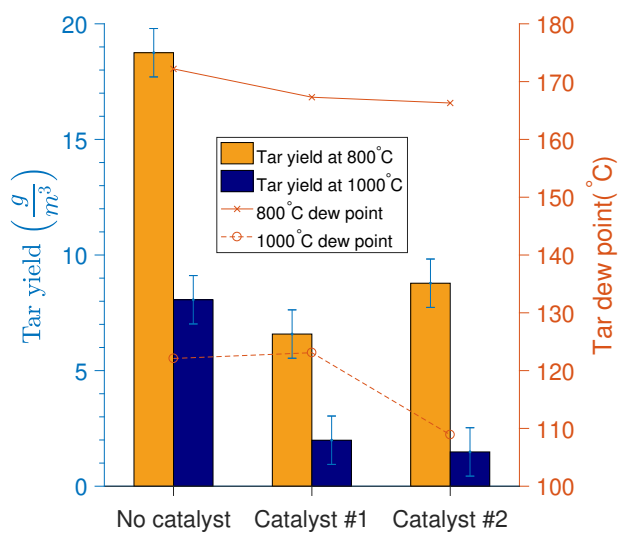

(a)

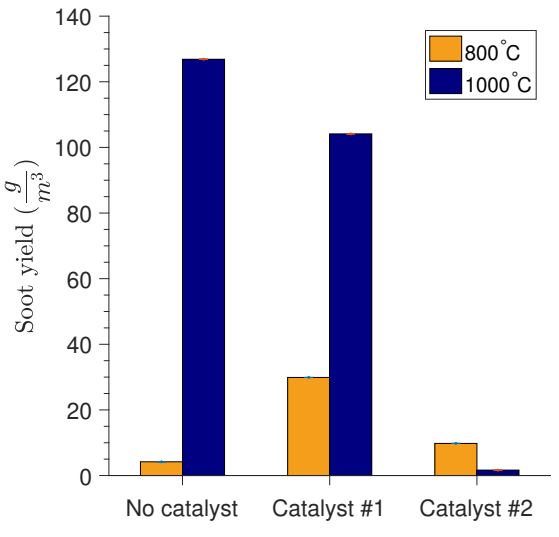

(b)

Figure 5: Tar yield and tar dew point (left, where bars are read on the left and lines on the right) and soot yield (right). Tar dew point is estimated by using tar composition shown in table 5 in the tar dew point calculator provided by ECN [57] 


\subsection{Tar yield, tar composition and soot yield.}

The use of both catalysts reached gravimetric tar (class 5 tar) conversions with respect to the non-catalytic case of $53 \%$ and $65 \%$ at $800^{\circ} \mathrm{C}$ and $70 \%$ and $81 \%$ at $1000^{\circ} \mathrm{C}$ for catalyst $\# 1$ and $\# 2$ respectively, as can be calculated from the tar yields presented in figure 5a. These conversions are not that high compared to the conversion obtained by using supported metal catalysts (which are above $90 \%$ at similar temperature ranges) [74]. However, the production of soot, a byproduct of tar cracking, which tends to be more problematic than tar itself, decreased at high temperatures as it can be seen in figure 5b. The soot reduction was especially significant when using catalyst $\# 2$. The results at $800^{\circ} \mathrm{C}$ show that, although tar yield was reduced, soot yield is increased by both catalysts, with catalyst \#1 yielding the highest amount of soot.

Apart from soot reduction, catalyst \#2 changed the tar distribution (class 2 to 5) such that it decreased the estimated tar dew point from 123 to $109^{\circ} \mathrm{C}$ (calculated by using concentrations presented in table 5 in the tar dew point calculator given by the ECN [57]) when tar cracking was performed at $1000^{\circ} \mathrm{C}$, while with catalyst \#1 tar dew point remained invariable, as can be seen in figure 5a. Catalyst \#2 exhibited the highest reduction of heavy PAHs (acenapthylene, phenanthrene, fluoranthene and pyrene), between 38 to $60 \%$ with respect to the non-catalytic case at $1000^{\circ} \mathrm{C}$, increasing at the same time the amounts of toluene and benzene. Catalyst \#1 on the other hand yielded PAHs levels similar to the non-catalytic case at $1000^{\circ} \mathrm{C}$, as it can be seen

in table 5. The reduction of these PAHs levels is also directly linked to the low soot yield since PAHs are known as precursors of the macroaromatic 


\begin{tabular}{lllllll}
\hline Sample & A & F & C & B & E & D \\
Number & & & & & & \\
\hline Secondary & 800 & 800 & 800 & 1000 & 1000 & 1000 \\
tar cracking temperature $\left({ }^{\circ} \mathrm{C}\right)$ & & & & & & \\
\hline Catalytst & No catalyst & Catalyst $\# 1$ & Catalyst $\# 2$ & No catalyst & Catalyst \#1 & Catalyst \#2 \\
\hline Benzene & 40 & 13890 & 570 & 3540 & 14910 & 12190 \\
Toluene (Class 3) & 1250 & 17350 & 4780 & 110 & 230 & 230 \\
m/p-Xylene (Class 2) & 1980 & 1140 & 2140 & 60 & 90 & 70 \\
o-Xylene (Class 2) & 22300 & 15420 & 24630 & N.D. & 40 & N.D. \\
Indan (Class 3) & 860 & 390 & 710 & N.D. & N.D. & N.D. \\
Indene (Class 4) & 9250 & 5260 & 8700 & N.D. & N.D. & N.D. \\
Naphthalene (Class 4) & 39670 & 34360 & 34720 & 1930 & 2750 & 1870 \\
2-Methylnaphthalene $($ Class 4$)$ & 4720 & 2930 & 4490 & N.D. & N.D. & N.D. \\
1-Methylnaphthalene $($ Class 4$)$ & 2820 & 1610 & 2700 & N.D. & N.D. & N.D. \\
Biphenyl (Class 4) & 3510 & 3130 & 3560 & 60 & 70 & 40 \\
Acenaphthylene (Class 4) & 8580 & 7330 & 7740 & 560 & 540 & 240 \\
Acenaphthene (Class 4) & 820 & 560 & 870 & N.D. & N.D. & N.D. \\
Fluorene (Class 4) & 2560 & 1810 & 2140 & N.D. & N.D. & N.D. \\
Phenanthrene (Class 4) & 7780 & 6930 & 7280 & 370 & 350 & 230 \\
Anthracene (Class 4) & 2640 & 1810 & 2030 & N.D. & 30 & N.D. \\
Fluorantene (Class 5) & 1860 & 1680 & 1370 & 280 & 290 & 110 \\
Pyrene (Class 5) & 3450 & 2720 & 2370 & 300 & 310 & 120 \\
\hline Sum Aromatics & 114090 & 118310 & 110810 & 7220 & 19600 & 15100 \\
\hline Tar dew point $\left({ }^{\circ} \mathrm{C}\right)$ & 172 & 167 & 166 & 122 & 123 & 109 \\
\hline
\end{tabular}

Table 5: Tabulated tar distribution of tar class 2 to class 5 under non-catalytic and catalytic tar cracking. (N.D.) stands for not detected. All the concentrations are expressed in $\mathrm{mg} \mathrm{Nm}^{-3}$.

structure of soot [75]. On the other hand, at $800^{\circ} \mathrm{C}$ the PAHs levels were equally reduced by both catalysts, demonstrating that at this temperature the different characteristic of the catalysts ( crystallite size and porosity) do not affect greatly tar yield but strongly affect soot selectivity, since catalyst \#1 yields almost 3 times more soot than catalyst \#2.

The mechanism of catalytic cracking of tar using $\mathrm{CaO}$ has been described 
by [76], on which many pathways are examined over three model molecules thermodynamically. The most viable mechanism found consists of a dehydrogenation followed by adsorption of the radical over an oxygen atom instead of a calcium one. Chen et al. [76] results also indicate that it is possible that pure aromatic molecules, can be more easily cracked using $\mathrm{CaO}$ than certain aromatic molecules with heterocyclic components, like toluene, which may explain the higher conversion of PAHs in favor of a production of monosubstituted aromatics such as toluene.

\section{Conclusions}

In this study, producer gas obtained from MSW gasification is cleaned by tar cracking using mussels and oyster shells-derived materials. Both materials demonstrated improved syngas yields at low temperatures with a simultaneous tar yield reduction despite their low specific surface areas (SSA). At high temperatures however, the oyster-derived catalyst demonstrated to be more promising for tar removal because, although it barely affects syngas yield, it increased the quality of the syngas by reducing the soot yield, reducing the PAHs concentrations and by simultaneously rising the $\mathrm{H}_{2} / \mathrm{CO}$ ratio to a value close to 2.8 , which is above the requirement set for Fischer-Tropsch synthesis using cobalt $[77,78]$ and iron catalysts. This high $\mathrm{H}_{2} / \mathrm{CO}$ ratio is however accompanied by higher $\mathrm{CH}_{4}$ and $\mathrm{C}_{2}$-gases volume fractions.

The primary reason for the better performance of the oyster shells-based catalyst seems to be related to the crystallite size and especially the SSA, which is almost twice as large as the one found in mussel shells-based catalyst. The reason why this higher SSA derives in a higher reactivity is that a higher 
SSA is connected to more reactive sites in the oyster-derived catalyst than in the mussel-derived catalyst. On the other hand, a bigger crystallite size favors specific catalytic processes $[79,80]$, due to an increased diffusion time through the crystal, which affects, therefore, the product distribution.

Nevertheless, this crystallite size and porosity difference did not influence strongly tar and syngas yield. The oyster shells-based catalyst also shows better thermal stability, by keeping its pore size after the calcination process.

The oyster-derived catalyst exhibited to be a promising material to be used for tar abatement in gasification in tandem with $\mathrm{Ni}$ - and noble metalssupported catalysts (or serving as plausible support) due to three main reasons. The first one is that gravimetric tar levels fell below $2 \mathrm{~g} \mathrm{Nm}^{-3}$ (which was also obtained with mussel-derived catalysts), which has been suggested as a threshold to avoid coking in Ni-supported catalysts [81]. The second reason is that the oyster-based catalyst reduced PAHs by simultaneously increasing light aromatics, which can reduce coking in Ni- and Rh-based catalysts as demonstrated by Laprune et al. [82] where the poisoning effect of light hydrocarbons is minor compared to the one of PAHs. And because the $\mathrm{CaO}$ content in the oyster-derived catalyst can protect the metal-supported catalysts from deactivation by $\mathrm{H}_{2} \mathrm{~S}$, which is considered critical because is hardly reversible [83]. This resistance to $\mathrm{H}_{2} \mathrm{~S}$ deactivation has been already demonstrated by Hernandez et al. [84] with other materials containing $\mathrm{CaO}$.

\section{Acknowledgement}

The research leading to these results has received funding from the European Community's Horizon 2020 Programme under Grant Agreement No. 
721185 (MSCA- ETN NEW-MINE, http://new-mine.eu/). Special thanks to M.Sc. Arango for her valuable discussions over the catalysts characterization.

\section{References}

[1] UN General Assembly, Transforming our world : the 2030 agenda for sustainable development, 2019. Https://www.refworld.org/docid/57b6e3e44.html, Last accessed on 2019-09-11.

[2] P. T. Jones, D. Geysen, Y. Tielemans, S. V. Passel, Y. Pontikes, B. Blanpain, M. Quaghebeur, N. Hoekstra, Enhanced landfill mining in view of multiple resource recovery: a critical review, Journal of Cleaner Production 55 (2013) 45 - 55. URL: http://www.sciencedirect.com/science/article/pii/S0959652612002442. doi:10.1016/j.jclepro.2012.05.021, special Volume: Urban and Landfill Mining.

[3] A. Bosmans, I. Vanderreydt, D. Geysen, L. Helsen, The crucial role of waste-to-energy technologies in enhanced landfill mining: a technology review, Journal of Cleaner Production 55 (2013) 10 - 23. URL: http://www.sciencedirect.com/science/article/pii/S0959652612002557. doi:https://doi.org/10.1016/j.jclepro.2012.05.032, special Volume: Urban and Landfill Mining.

[4] I. Pieta, W. Epling, A. Kazmierczuk, P. Lisowski, R. Nowakowski, E. Serwicka, Waste into Fuel-Catalyst and Process Development for MSW Valorisation, Catalysts 8 (2018) 
113. URL: http://dx.doi.org/10.3390/catal8030113. doi:10.3390/catal8030113.

[5] L. Devi, K. J. Ptasinski, F. J. Janssen, A review of the primary measures for tar elimination in biomass gasification processes, Biomass and Bioenergy 24 (2003) 125 - 140. URL: http://www.sciencedirect.com/science/article/pii/S0961953402001022. doi:http://dx.doi.org/10.1016/S0961-9534(02)00102-2.

[6] N. Kamińska-Pietrzak, A. Smoliński, Selected environmental aspects of gasification and co-gasification of various types of waste, Journal of Sustainable Mining 12 (2013) 6 - 13. URL: http://www.sciencedirect.com/science/article/pii/S230039601530063X. doi:https://doi.org/10.7424/jsm130402.

[7] M. Hawrot-Paw, A. Koniuszy, M. Mikiciuk, M. Izwikow, T. Stawicki, P. Sedłak, Analysis of ecotoxic influence of waste from the biomass gasification process, Environmental Science and Pollution Research 24 (2017) 15022-15030. URL: https://doi.org/10.1007/s11356-017-9011-8. doi:10.1007/s11356-017-9011-8.

[8] S. Safarian, R. Unnbórsson, C. Richter, A review of biomass gasification modelling, Renewable and Sustainable Energy Reviews 110 (2019) 378 - 391. URL: http://www.sciencedirect.com/science/article/pii/S1364032119303090. doi:https://doi.org/10.1016/j.rser.2019.05.003.

[9] V. Claude, C. Courson, M. Köhler, S. D. Lambert, Overview 
and essentials of biomass gasification technologies and their catalytic cleaning methods, Energy \& Fuels 30 (2016) 8791-8814. doi:10.1021/acs.energyfuels.6b01642.

[10] K. Tomishige, T. Miyazawa, M. Asadullah, S.-i. Ito, K. Kunimori, Catalyst performance in reforming of tar derived from biomass over noble metal catalysts, Green Chem. 5 (2003) 399-403. URL: http://dx.doi .org/10.1039/B303371F. doi:10.1039/B303371F.

[11] G. Guan, M. Kaewpanha, X. Hao, A. Abudula, Catalytic steam reforming of biomass tar: Prospects and challenges, Renewable and Sustainable Energy Reviews 58 (2016) 450 - 461. URL: http://www. sciencedirect.com/science/article/pii/S1364032115016998. doi:https://doi.org/10.1016/j.rser.2015.12.316.

[12] L. Liu, Z. Zhang, S. Das, S. Kawi, Reforming of tar from biomass gasification in a hybrid catalysis-plasma system: A review, Applied Catalysis B: Environmental 250 (2019) 250 - 272. URL: http://www.sciencedirect.com/science/article/pii/S0926337319302553. doi:https://doi.org/10.1016/j.apcatb.2019.03.039.

[13] R. Frazier, E. Jin, A. Kumar, Life cycle assessment of biochar versus metal catalysts used in syngas cleaning, Energies 8 (2015) 621-644. URL: http://dx.doi .org/10 .3390/en8010621. doi:10.3390/en8010621.

[14] A. Veses, M. Aznar, J. López, M. Callén, R. Murillo, T. García, Production of upgraded bio-oils by biomass catalytic pyrolysis in an 
auger reactor using low cost materials, Fuel 141 (2015) 17 - 22. URL:

http://www.sciencedirect.com/science/article/pii/S0016236114010394. doi:https://doi.org/10.1016/j.fuel.2014.10.044.

[15] S. Sushil, V. S. Batra, Catalytic applications of red mud, an aluminium industry waste: A review, Applied Catalysis B: Environmental 81 (2008) 64 - 77 . URL: http://www.sciencedirect.com/science/article/pii/S0926337307004468. doi:https://doi.org/10.1016/j.apcatb.2007.12.002.

[16] H. T. Van, L. H. Nguyen, T. K. Hoang, T. P. Tran, A. T. Vo, T. Pham, X. Nguyen, Using FeO-constituted iron slag wastes as heterogeneous catalyst for fenton and ozonation processes to degrade Reactive Red 24 from aqueous solution, Separation and Purification Technology 224 (2019) 431 - 442. URL: http://www.sciencedirect.com/science/article/pii/S1383586619309955. doi:https://doi.org/10.1016/j.seppur.2019.05.048.

[17] M. Balakrishnan, V. S. Batra, J. S. J. Hargreaves, I. D. Pulford, Waste materials - catalytic opportunities: an overview of the application of large scale waste materials as resources for catalytic applications, Green Chem. 13 (2011) 16-24. URL: http://dx.doi.org/10.1039/C0GC00685H. doi:10.1039/C0GC00685H.

[18] S. Nakamura, S. Kitano, K. Yoshikawa, Biomass gasification process with the tar removal technologies utilizing bio-oil scrubber and char bed, Applied Energy 170 (2016) 186 - 192. URL: 
http://www.sciencedirect.com/science/article/pii/S0306261916302690. doi:https://doi.org/10.1016/j.apenergy.2016.02.113.

[19] N. Wang, D. Chen, U. Arena, P. He, Hot charcatalytic reforming of volatiles from MSW pyrolysis, Applied Energy 191 (2017) 111 - 124. URL: http://www. sciencedirect. com/science/article/pii/S0306261917300594. doi:https://doi.org/10.1016/j.apenergy.2017.01.051.

[20] A. S. Al-Rahbi, P. T. Williams, Hydrogen-rich syngas production and tar removal from biomass gasification using sacrificial tyre pyrolysis char, Applied Energy 190 (2017) 501 - 509. URL: http://www. sciencedirect.com/science/article/pii/S0306261916318700. doi:https://doi.org/10.1016/j.apenergy.2016.12.099.

[21] Y. Shen, Y. Fu, Advances in in situ and ex situ tar reforming with biochar catalysts for clean energy production, Sustainable Energy Fuels 2 (2018) 326-344. URL: http://dx.doi .org/10.1039/C7SE00553A. doi:10.1039/C7SE00553A.

[22] L. von Berg, C. Doğan, E. S. Aydın, S. Retschitzegger, R. Scharler, A. Anca-Couce, Catalytic tar reforming with sewage sludge char of a producer gas from fluidized bed co-gasification of sewage sludge and wood, in: European Biomass Conference and Exhibition Proceedings, 2019, pp. 523-526. URL: www. scopus. com.

[23] D. Buentello-Montoya, X. Zhang, J. Li, The use of gasification solid products as catalysts for tar reforming, Renewable 
and Sustainable Energy Reviews 107 (2019) 399 - 412. URL: http://www.sciencedirect.com/science/article/pii/S1364032119301601. doi:https://doi.org/10.1016/j.rser.2019.03.021.

[24] J. Ashok, S. Das, T. Yeo, N. Dewangan, S. Kawi, Incinerator bottom ash derived from municipal solid waste as a potential catalytic support for biomass tar reforming, Waste Management 82 (2018) 249 - 257. URL: http://www.sciencedirect.com/science/article/pii/S0956053X18306548. doi:https://doi.org/10.1016/j.wasman.2018.10.035.

[25] R. Blissett, N. Rowson, A review of the multi-component utilisation of coal fly ash, Fuel 97 (2012) $1-23$. URL: http://www.sciencedirect.com/science/article/pii/S0016236112002335. doi:https://doi.org/10.1016/j.fuel.2012.03.024.

[26] J. Boro, D. Deka, A. J. Thakur, A review on solid oxide derived from waste shells as catalyst for biodiesel production, Renewable and Sustainable Energy Reviews 16 (2012) 904 - 910. URL: http://www.sciencedirect.com/science/article/pii/S1364032111004618. doi:https://doi.org/10.1016/j.rser.2011.09.011.

[27] W. Suryaputra, I. Winata, N. Indraswati, S. Ismadji, Waste capiz (amusium cristatum) shell as a new heterogeneous catalyst for biodiesel production, Renewable Energy 50 (2013) 795 - 799. URL: http://www.sciencedirect.com/science/article/pii/S0960148112005307. doi:https://doi.org/10.1016/j.renene.2012.08.060.

[28] R. Shan, C. Zhao, P. Lv, H. Yuan, J. Yao, Catalytic applications of 
calcium rich waste materials for biodiesel: Current state and perspectives, Energy Conversion and Management 127 (2016) 273 - 283. URL: http://www. sciencedirect. com/science/article/pii/S0196890416307968. doi:https://doi.org/10.1016/j.enconman.2016.09.018.

[29] N. Mansir, S. H. Teo, U. Rashid, Y. H. Taufiq-Yap, Efficient waste gallus domesticus shell derived calcium-based catalyst for biodiesel production, Fuel 211 (2018) 67 - 75. URL: http://www.sciencedirect.com/science/article/pii/S0016236117311146. doi:https://doi.org/10.1016/j.fuel.2017.09.014.

[30] N. Mansir, S. H. Teo, U. Rashid, M. I. Saiman, Y. P. Tan, G. A. Alsultan, Y. H. Taufiq-Yap, Modified waste egg shell derived bifunctional catalyst for biodiesel production from high ffa waste cooking oil. A review, Renewable and Sustainable Energy Reviews 82 (2018) 3645 - 3655. URL: http://www.sciencedirect.com/science/article/pii/S1364032117314752. doi:https://doi.org/10.1016/j.rser.2017.10.098.

[31] R. Risso, P. Ferraz, S. Meireles, I. Fonseca, J. Vital, Highly active cao catalysts from waste shells of egg, oyster and clam for biodiesel production, Applied Catalysis A: General 567 (2018) 56 - 64. URL: http://www.sciencedirect.com/science/article/pii/S0926860X18304344. doi:https://doi.org/10.1016/j.apcata.2018.09.003.

[32] R. Shan, L. Lu, Y. Shi, H. Yuan, J. Shi, Catalysts from renewable resources for biodiesel production, Energy Conversion and Management 178 (2018) 277 - 289. URL: 
http://www.sciencedirect.com/science/article/pii/S0196890418311324. doi:https://doi.org/10.1016/j.enconman.2018.10.032.

[33] R. B. Narayan, R. Goutham, B. Srikanth, K. Gopinath, A novel nano-sized calcium hydroxide catalyst prepared from clam shells for the photodegradation of methyl red dye, Journal of Environmental Chemical Engineering 6 (2018) 3640 - 3647. URL: http://www.sciencedirect.com/science/article/pii/S2213343716304444. doi:https://doi.org/10.1016/j.jece.2016.12.004.

[34] S. Castilho, A. Kiennemann, M. F. C. Pereira, A. P. S. Dias, Sorbents for $\mathrm{CO}_{2}$ capture from biogenesis calcium wastes, Chemical Engineering Journal 226 (2013) 146 - 153. URL: http://www. sciencedirect.com/science/article/pii/S1385894713004956. doi:https://doi.org/10.1016/j.cej.2013.04.017.

[35] T. Wang, D.-C. Xiao, C.-H. Huang, Y.-K. Hsieh, C.-S. Tan, C.-F. Wang, $\mathrm{CO}_{2}$ uptake performance and life cycle assessment of CaO-based sorbents prepared from waste oyster shells blended with pmma nanosphere scaffolds, Journal of Hazardous Materials 270 (2014) 92 - 101. URL: http://www.sciencedirect.com/science/article/pii/S0304389414000405. doi:https://doi.org/10.1016/j.jhazmat.2014.01.026.

[36] K. Qin, T. H. Wang, J.-C. Huang, C.-H. Huang, Y.-K. Hsieh, C.-F. Wang, C.-S. Tan, Effect of distribution patterns of refractory overlayers on cyclic high temperature $\mathrm{CO}_{2}$ capture using waste oyster shell, RSC Adv. 6 (2016) 97739-97748. URL: http://dx.doi.org/10.1039/C6RA20500C. doi:10.1039/C6RA20500C. 
[37] X. Ma, Y. Li, L. Duan, E. Anthony, H. Liu, $\mathrm{CO}_{2}$ capture performance of calcium-based synthetic sorbent with hollow core-shell structure under calcium looping conditions, Applied Energy 225 (2018) 402 - 412. URL: http://www.sciencedirect.com/science/article/pii/S0306261918307013. doi:https://doi.org/10.1016/j.apenergy.2018.05.008.

[38] L. P. L. M. Rabou, R. W. R. Zwart, B. J. Vreugdenhil, L. Bos, Tar in biomass producer gas, the energy research centre of the netherlands (ECN) experience: An enduring challenge, Energy \& Fuels 23 (2009) 6189-6198. doi:10.1021/ef9007032.

[39] L. Devi, K. J. Ptasinski, F. J. Janssen, Pretreated olivine as tar removal catalyst for biomass gasifiers: investigation using naphthalene as model biomass tar, Fuel Processing Technology 86 (2005) 707 - 730. URL: http://www. sciencedirect.com/science/article/pii/S0378382004001535. doi:https://doi.org/10.1016/j.fuproc.2004.07.001.

[40] H. O. Fredriksson, R. J. Lancee, P. C. Thüne, H. J. Veringa, J. H. Niemantsverdriet, Olivine as tar removal catalyst in biomass gasification: Catalyst dynamics under model conditions, Applied Catalysis B: Environmental 130-131 (2013) 168 - 177. URL: http://www. sciencedirect.com/science/article/pii/S0926337312004857. doi:https://doi.org/10.1016/j.apcatb.2012.10.017.

[41] R. Lancee, A. Dugulan, P. Thüne, H. Veringa, J. Niemantsverdriet, H. Fredriksson, Chemical looping capabilities of olivine, used as a catalyst in indirect biomass gasification, Applied Catalysis B: Environmental 145 (2014) 216 - 222. URL: 
http://www.sciencedirect.com/science/article/pii/S0926337313000611. doi:https://doi.org/10.1016/j.apcatb.2013.01.041, advances in Catalysis for Biomass Valorization.

[42] C. Christodoulou, D. Grimekis, K. Panopoulos, E. Pachatouridou, E. Iliopoulou, E. Kakaras, Comparing calcined and un-treated olivine as bed materials for tar reduction in fluidized bed gasification, Fuel Processing Technology 124 (2014) 275 - 285. URL: http://www.sciencedirect.com/science/article/pii/S0378382014001088. doi:https://doi.org/10.1016/j.fuproc.2014.03.012.

[43] C. P. Quitete, M. M. Souza, Application of brazilian dolomites and mixed oxides as catalysts in tar removal system, Applied Catalysis A: General 536 (2017) 1 - 8. URL: http://www.sciencedirect.com/science/article/pii/S0926860X17300698. doi:https://doi.org/10.1016/j.apcata.2017.02.014.

[44] P. Knutsson, V. Cantatore, M. Seemann, P. L. Tam, I. Panas, Role of potassium in the enhancement of the catalytic activity of calcium oxide towards tar reduction, Applied Catalysis B: Environmental 229 (2018) 88 - 95. URL: http://www.sciencedirect.com/science/article/pii/S0926337318301097. doi:https://doi.org/10.1016/j.apcatb.2018.02.002.

[45] C. Zhou, C. Rosén, K. Engvall, Selection of dolomite bed material for pressurized biomass gasification in BFB, Fuel Processing Technology 159 (2017) 460 - 473. URL: 
http://www.sciencedirect.com/science/article/pii/S0378382017300437. doi:https://doi.org/10.1016/j.fuproc.2017.01.008.

[46] Y. Tursun, S. Xu, A. Abulikemu, T. Dilinuer, Biomass gasification for hydrogen rich gas in a decoupled triple bed gasifier with olivine and NiO/olivine, Bioresource Technology 272 (2019) 241 - 248. URL: http://www. sciencedirect. com/science/article/pii/S0960852418314226. doi:https://doi.org/10.1016/j.biortech.2018.10.008.

[47] G. Hu, S. Xu, S. Li, C. Xiao, S. Liu, Steam gasification of apricot stones with olivine and dolomite as downstream catalysts, Fuel Processing Technology 87 (2006) 375 - 382. URL: http://www.sciencedirect.com/science/article/pii/S0378382005002031. doi:https://doi.org/10.1016/j.fuproc.2005.07.008.

[48] Q.-Z. Yu, C. Brage, T. Nordgreen, K. Sjöström, Effects of chinese dolomites on tar cracking in gasification of birch, Fuel 88 (2009) 1922 - 1926. URL: http://www.sciencedirect.com/science/article/pii/S0016236109001707. doi:https://doi.org/10.1016/j.fuel.2009.04.020.

[49] J. González, S. Román, G. Engo, J. Encinar, G. Martínez, Reduction of tars by dolomite cracking during two-stage gasification of olive cake, Biomass and Bioenergy 35 (2011) 4324 - 4330. URL: http://www. sciencedirect.com/science/article/pii/S0961953411004314. doi:https://doi.org/10.1016/j.biombioe.2011.08.001.

[50] A. Sarığlan, Tar removal on dolomite and steam reforming 
catalyst: Benzene, toluene and xylene reforming, International Journal of Hydrogen Energy 37 (2012) 8133 - 8142. URL: http://www.sciencedirect.com/science/article/pii/S0360319912003679. doi:https://doi.org/10.1016/j.ijhydene.2012.02.045, international Conference: Photosynthesis Research for Sustainability.

[51] G. Guan, M. Kaewpanha, X. Hao, A. min Zhu, Y. Kasai, S. Kakuta, K. Kusakabe, A. Abudula, Steam reforming of tar derived from lignin over pompom-like potassiumpromoted iron-based catalysts formed on calcined scallop shell, Bioresource Technology 139 (2013) 280 - 284. URL: http://www.sciencedirect.com/science/article/pii/S0960852413006111. doi:https://doi.org/10.1016/j.biortech.2013.04.007.

[52] G. Guan, M. Kaewpanha, X. Hao, Z. Wang, Y. Cheng, Y. Kasai, A. Abudula, Promoting effect of potassium addition to calcined scallop shell supported catalysts for the decomposition of tar derived from different biomass resources, Fuel 109 (2013) 241 - 247. URL: http://www.sciencedirect.com/science/article/pii/S0016236112010125. doi:https://doi.org/10.1016/j.fuel.2012.11.074.

[53] J. Yang, M. Kaewpanha, S. Karnjanakom, G. Guan, X. Hao, A. Abudula, Steam reforming of biomass tar over calcined egg shell supported catalysts for hydrogen production, International Journal of Hydrogen Energy 41 (2016) 6699 - 6705. URL: http://www.sciencedirect.com/science/article/pii/S0360319915319303. doi:https://doi.org/10.1016/j.ijhydene.2016.03.056. 
[54] M. Kaewpanha, S. Karnjanakom, G. Guan, X. Hao, J. Yang, A. Abudula, Removal of biomass tar by steam reforming over calcined scallop shell supported $\mathrm{Cu}$ catalysts, Journal of Energy Chemistry 26 (2017) 660 - 666. URL: http://www.sciencedirect.com/science/article/pii/S2095495616301863. doi:https://doi.org/10.1016/j.jechem.2017.03.012.

[55] M. Quaghebeur, B. Laenen, D. Geysen, P. Nielsen, Y. Pontikes, T. V. Gerven, J. Spooren, Characterization of landfilled materials: screening of the enhanced landfill mining potential, Journal of Cleaner Production 55 (2013) 72 - 83. URL: http://www.sciencedirect.com/science/article/pii/S095965261200306X. doi:https://doi.org/10.1016/j.jclepro.2012.06.012, special Volume: Urban and Landfill Mining.

[56] FAO, Agriculture Organization of the United Nations. 2016. The State of World Fisheries and Aquaculture 2016. Contributing to food security and nutrition for all. Rome. 200 pp, 2018.

[57] ECN, Tar dew point calculator, http://www .thersites.nl/completemodel .aspx, 2018. Last accessed on 27th September 2019.

[58] C. García-Lopez, A. Ni, J. C. Hernández-Parrodi, T. Pretz, K. Raulf, B. Küppers, Characterization of landfill mining material after ballistic separation to evaluate material and energy recovery potential, Detritus (2019). doi:https://doi:10.31025/2611-4135/2019.13780.

[59] J. S. Tumuluru, E. Fillerup, Briquetting characteristics of 
woody and herbaceous biomass blends: Impact on physical properties, chemical composition, and calorific value, Biofuels, Bioproducts and Biorefining 14 (2020) 1105-1124. URL: https://onlinelibrary.wiley.com/doi/abs/10.1002/bbb. 2121. doi:10.1002/bbb.2121.

[60] Z.-K. Li, H.-L. Yan, J.-C. Yan, Z.-C. Wang, Z.-P. Lei, S.-B. Ren, H.-F. Shui, Drying and depolymerization technologies of zhaotong lignite: A review, Fuel Processing Technology 186 (2019) 88 - 98. URL: http://www.sciencedirect.com/science/article/pii/S0378382018322173. doi:https://doi.org/10.1016/j.fuproc.2019.01.002.

[61] S. Wang, H. Persson, W. Yang, P. G. Jönsson, Pyrolysis study of hydrothermal carbonization-treated digested sewage sludge using a py-gc/ms and a bench-scale pyrolyzer, Fuel 262 (2020) 116335. URL: http://www.sciencedirect.com/science/article/pii/S0016236119316898. doi:https://doi.org/10.1016/j.fuel.2019.116335.

[62] A. R. Saleh, B. Sudarmanta, H. Fansuri, O. Muraza, Syngas production from municipal solid waste with a reduced tar yield by three-stages of air inlet to a downdraft gasifier, Fuel 263 (2020) 116509. URL: http://www.sciencedirect.com/science/article/pii/S0016236119318630. doi:https://doi.org/10.1016/j.fuel.2019.116509.

[63] C. Brage, Q. Yu, G. Chen, K. Sjöström, Use of amino phase adsorbent for biomass tar sampling and separation, Fuel 76 (1997) 137 - 142. URL: http://www.sciencedirect.com/science/article/pii/S0016236196001998. doi:https://doi.org/10.1016/S0016-2361(96)00199-8. 
[64] S. Zhang, M. Asadullah, L. Dong, H.-L. Tay, C.-Z. Li, An advanced biomass gasification technology with integrated catalytic hot gas cleaning. part ii: Tar reforming using char as a catalyst or as a catalyst support, Fuel 112 (2013) 646 - 653. URL: http://www.sciencedirect. com/science/article/pii/S0016236113002032. doi:https://doi.org/10.1016/j.fuel.2013.03.015.

[65] Y.-H. Chen, M. Schmid, T. Kertthong, G. Scheffknecht, Reforming of toluene as a tar model compound over straw char containing fly ash, Biomass and Bioenergy 141 (2020) 105657. URL: http://www.sciencedirect.com/science/article/pii/S0961953420301914. doi:https://doi.org/10.1016/j.biombioe.2020.105657.

[66] G.-Y. Chen, C. Liu, W.-C. Ma, B.-B. Yan, N. Ji, Catalytic cracking of tar from biomass gasification over a hzsm5-supported ni-mgo catalyst, Energy \& Fuels 29 (2015) 79697974. URL: https://doi.org/10.1021/acs.energyfuels.5b00830. doi:10.1021/acs.energyfuels.5b00830. arXiv:https://doi.org/10.1021/acs.energyfuels . 5

[67] J. N. Kuhn, Z. Zhao, L. G. Felix, R. B. Slimane, C. W. Choi, U. S. Ozkan, Olivine catalysts for methane- and tar-steam reforming, Applied Catalysis B: Environmental 81 (2008) 14 - 26. URL: http://www.sciencedirect.com/science/article/pii/S0926337307004444. doi:https://doi.org/10.1016/j.apcatb.2007.11.040.

[68] M. Cortazar, G. Lopez, J. Alvarez, M. Amutio, J. Bilbao, M. Olazar, Behaviour of primary catalysts in the biomass steam gasification in a fountain confined spouted bed, Fuel 253 (2019) 1446 - 1456. URL: 
http://www.sciencedirect.com/science/article/pii/S0016236119308476. doi:https://doi.org/10.1016/j.fuel.2019.05.094.

[69] J. Meng, Z. Zhao, X. Wang, J. Chen, A. Zheng, Z. Huang, G. Wei, H. Li, Steam reforming and carbon deposition evaluation of phenol and naphthalene used as tar model compounds over ni and fe olivine-supported catalysts, Journal of the Energy Institute 92 (2019) 1765 - 1778. URL: http://www.sciencedirect.com/science/article/pii/S1743967118305543. doi:https://doi.org/10.1016/j.joei.2018.12.004.

[70] X. Bao, M. Kong, W. Lu, J. Fei, X. Zheng, Performance of co/mgo catalyst for co2 reforming of toluene as a model compound of tar derived from biomass gasification, Journal of Energy Chemistry 23 (2014) 795 - 800. URL: http://www.sciencedirect.com/science/article/pii/S209549561460214X. doi:https://doi.org/10.1016/S2095-4956(14)60214-X.

[71] W. Peng, L. Wang, M. Mirzaee, H. Ahmadi, M. Esfahani, S. Fremaux, Hydrogen and syngas production by catalytic biomass gasification, Energy Conversion and Management 135 (2017) 270 - 273. URL: http://www.sciencedirect.com/science/article/pii/S0196890416311359. doi:https://doi.org/10.1016/j.enconman.2016.12.056.

[72] S. Ning, S. Jia, H. Ying, Y. Sun, W. Xu, H. Yin, Hydrogenrich syngas produced by catalytic steam gasification of corncob char, Biomass and Bioenergy 117 (2018) 131 - 136. URL: http://www.sciencedirect.com/science/article/pii/S0961953418301673. doi:https://doi.org/10.1016/j.biombioe.2018.07.003. 
[73] A. Vargas-Mira, C. Zuluaga-Garcia, A. D. Gonzalez-Delgado, A technical and environmental evaluation of six routes for industrial hydrogen production from empty palm fruit bunches, ACS Omega 4 (2019) 15457-15470. URL: https://doi.org/10.1021/acsomega.9b01683. doi:10.1021/acsomega.9b01683. arXiv:https://doi .org/10.1021/acsomega.9b01683.

[74] Z. Zhang, L. Liu, B. Shen, C. Wu, Preparation, modification and development of ni-based catalysts for catalytic reforming of tar produced from biomass gasification, Renewable and Sustainable Energy Reviews 94 (2018) 1086 - 1109. URL: http://www.sciencedirect.com/science/article/pii/S1364032118305045. doi:https://doi.org/10.1016/j.rser.2018.07.010.

[75] Y. Han, B. Bandowe, C. Wei, J. Cao, W. Wilcke, G. Wang, H. Ni, Z. Jin, Z. An, B. Yan, Stronger association of polycyclic aromatic hydrocarbons with soot than with char in soils and sediments, Chemosphere 119 (2015) 1335 - 1345. URL: http://www.sciencedirect.com/science/article/pii/S0045653514002240. doi:https://doi.org/10.1016/j.chemosphere.2014.02.021.

[76] B. Chen, Z.-M. Shi, S.-J. Jiang, H. Tian, Catalytic cracking mechanisms of tar model compounds, Journal of Central South University 23 (2016) 3100-3107. doi:10.1007/s11771-016-3375-7.

[77] S. S. Ail, S. Dasappa, Biomass to liquid transportation fuel via fischer tropsch synthesis - technology review and current scenario, Renewable and Sustainable Energy Reviews 58 (2016) 267 - 286. URL: 
http://www.sciencedirect.com/science/article/pii/S1364032115015269. doi:https://doi.org/10.1016/j.rser.2015.12.143.

[78] S. Abelló, D. Montané, Exploring iron-based multifunctional catalysts for fischer-tropsch synthesis: A review, ChemSusChem 4 (2011) 1538-1556. URL: https://doi .org/10.1002/cssc. 201100189. doi:10.1002/cssc.201100189.

[79] T. Sirikajorn, O. Mekasuwandumrong, P. Praserthdam, J. Goodwin Jr., J. Panpranot, Effect of support crystallite size on catalytic activity and deactivation of nanocrystalline znal2o4-supported pd catalysts in liquid-phase hydrogenation, Catalysis Letters 126 (2008) 313-318. doi:10.1007/s10562-008-9621-3.

[80] A. B. D. Nandiyanto, R. Zaen, R. Oktiani, Correlation between crystallite size and photocatalytic performance of micrometer-sized monoclinic wo3 particles, Arabian Journal of Chemistry 13 (2020) 1283 - 1296. URL: http://www.sciencedirect.com/science/article/pii/S1878535217302046. doi:https://doi.org/10.1016/j.arabjc.2017.10.010.

[81] Z. Abu El-Rub, E. A. Bramer, G. Brem, Review of catalysts for tar elimination in biomass gasification processes, Industrial \& Engineering Chemistry Research 43 (2004) 6911-6919. URL: https://doi.org/10.1021/ie0498403. doi:10.1021/ie0498403. arXiv:https://doi.org/10.1021/ie0498403.

[82] D. Laprune, C. Theodoridi, A. Tuel, D. Farrusseng, F. Meu- 
nier, Effect of polyaromatic tars on the activity for methane steam reforming of nickel particles embedded in silicalite-1, Applied Catalysis B: Environmental 204 (2017) 515 - 524. URL: http://www. sciencedirect. com/science/article/pii/S0926337316309341. doi:https://doi.org/10.1016/j.apcatb.2016.12.004.

[83] X. Chen, J. Jiang, F. Yan, K. Li, S. Tian, Y. Gao, H. Zhou, Dry reforming of model biogas on a $\mathrm{Ni} / \mathrm{SiO}_{2}$ catalyst: Overall performance and mechanisms of sulfur poisoning and regeneration, ACS Sustainable Chemistry \& Engineering 5 (2017) 1024810257. URL: https://doi.org/10.1021/acssuschemeng.7b02251. doi:10.1021/acssuschemeng.7b02251.

[84] A. D. Hernandez, N. Kaisalo, P. Simell, M. Scarsella, Effect of $\mathrm{H}_{2} \mathrm{~S}$ and thiophene on the steam reforming activity of nickel and rhodium catalysts in a simulated coke oven gas stream, Applied Catalysis B: Environmental 258 (2019) 117977. URL: http://www.sciencedirect.com/science/article/pii/S0926337319307234. doi:https://doi.org/10.1016/j.apcatb.2019.117977. 